\title{
APPLICATION OF ACTIVE LEARNING METHODS DURING PHYSICAL EDUCATION CLASS IN CASE OF SOME SELECTED COLLEGE OF TEACHERS EDUCATION IN OROMIA REGIONAL STATE
}

\section{ADEM MOHAMMEDNUR AHMED (MED)}

Lecturer at Robe Callege of Teachers Education, Deprtment of Physical Education, Oromia Regional State, Bale Robe, Ethiopia

\begin{abstract}
Active learning methods of teaching has many advantages in developing learners' knowledge and skills. But its advantage is realized only when it is effectively and properly implemented. Based on this, the main purpose of this study was to assess the status of Application of Active Learning Methods during Physical Education Class in Case of Same Selected Colleges of Teachers Education in Oromia Regional State. In order to meet the objectives of the study descriptive survey research method was employed. Three Colleges namely, Bale Robe, Asela, and Adola were selected out by this study. The researcher incorporated 50 female and 73 male students, 8 teachers and 3 College Deans were a primary sources of data. Questionnaires, interviews and observation were used for the purpose of collecting relevant data. Data obtained through questionnaires were analyzed using statistical tools like frequency, percentage, mean, average mean, chi square, and standard deviation. Moreover, data gathered through interview and observation were considered to triangulate the questionnaires in narrative form. The finding of this study revealed that the perceptions of teachers and students on the current active learning application process of physical education in different college of teacher's education in Oromia was tested. Some of these activities were found at low rate. Because, most activities were not performed all in all with more than 50\%. Also the study revealed that Active learning methods strategies like Discussion, group work, problem solving, peer teaching, think-pair-share, and cross over, pyramiding and jigsaw group were not applied by the teachers mostly used traditional lecture method. According to the result of the study, teachers' lack of shortage of instructional materials and facilities has affected the application of active learning methods. Finally the study revealed that large classes size, amount of content that needs to be covered, lack of administrative support, lack of classroom space, involve students in active learning will add too much to my work load and lack of understanding how to apply active learning were the most dominant challenges. In line with the above findings and conclusions it was recommended that the college deans and department heads of need to encourage teachers to use different active learning methods and extra teaching materials in the classroom to promote improved learning achievement.
\end{abstract}

KEYWORDS: Physical Education, Active Leaning Methods, Application of Active Learning \& Teaching

Received: Jun 08, 2020; Accepted: Jun 28, 2020; Published: Aug 31, 2020; Paper Id.: IJMPERDJUN2020978

\section{INTRODUCTION}

\subsection{Background of the Study}

Teaching is considered by modern pedagogues as "a process of facilitating individual's learning through motivation, coordination, guiding or directing the activities he or she performs and controlling or evaluating the learning results". Teaching is also defined as "a process of directing the interaction between the learner and the material to be learned", etc. 
Similar to teaching the psychologists differ in defining learning as indicated "Learning is the process of acquiring knowledge through the mental process. It is developing the mental caliber of the individual. Learning is a relatively permanent change or modification of the behavior of the learner as a result of practice." Here the change in behavior is related to the acquisition of knowledge, the development of skills, and the formation of value systems. In physical education

There is a special learning which is Motor learning; means learning through movement.

According to the Gallahue's model of motor development (1996), walking, running, hoping, galloping, skipping and sliding are some of the most important locomotor skills. The development of such a knowledge base facilitates children's motor engagement, decreasing errors in performance both in and out of the school setting (Derri \& Pachta, 2007, p.38)

Effective teaching and encouragement by the physical education teacher can enhance the development of such skills (Graham, Holt/Hale \& Parker, 2003). However, effective physical education teachers are those who not only master a wide variety of teaching styles and methods, but are also able to manipulate them so as to increase students' learning in all the dimensions of the curriculum (Garn \& Byra, 2002). As Ulrich and Ulrich state (1985), through the instruction of developmentally appropriate movement programs as well as through the implementation of effective teaching methods, students will improve their performance more than those who simply engage in free play activities.

Effective teaching and learning requires the use of various methodologies and pedagogies to meet the demands of the new generations, new techniques and the ever changing educational environments. The challenge is to find new ways to stimulate and motivate the creative abilities of today's generations who have different set of orientations towards learning more than most of us did as students. The traditional "chalk and talk" approach with the students as a recipient of knowledge may not suitable for today's generation. In the new approach to modern education, often called active learning, students not only receive information from lectures and book, they also collect information, record it systematically, discuss it, compare it, analysis it, draw conclusions from it and communicate about it (ICDR, 1999).

The new instructional model, active learning method intends to produce active and motivated learners who can cope with the demands of the modern world. Active learning methods encourage students' autonomous learning and problem solving skills. It provides pupils with greater personal satisfaction, more interactive with peers, promotion of shared activity and team work, greater opportunities to work with range of pupils and for all members of the class, to contribute and respond (Capel et.al. 1995). Active teaching and learning involves the use of different strategies, which are helpful in maximizing the opportunities for interaction. Indeed, some literature makes reference to "interactive" rather than active approach. In the active learning the learners have marked degree of freedom and control over the organization of learning activities which are usually problem solving, inquiry and investigational works. Similarly, Aggrawal (1996) has mentioned that the basic purpose of education is to enable the child to adapt him /her in a society, which is full of problems. Therefore, it is very important that problem solving skills encouraged in school learning.

In light of the above argument the new education and training policy of the Federal Democratic Republic of Ethiopia gives due attention for strengthening of the individuals` and societies' problem solving capacities at all levels. As stated in the policy (1994), one of the objectives is "to develop the physical and mental social well binges and problem solving capacity of individuals by expanding basic education for all". But there is a great gap between the idea of the 
policy and its implementation (theory and practice). This is to mean that what has been stated in the policy might not be implemented practically. Supporting this idea, Lue, (2000), as cited in Fiseha (2001) by saying the following statements; The kind of simple memorization and recall of facts and information (teacher centered) still forms the basis of much of our curriculum and instructional materials which is very damaging intellectually to the young learners. This damage comes from the fact that, this approach restricts our young learners to the most very simple and elementary thinking skills and does not help them to develop higher order skills. It is generally believed that, the impact of active learning in the teaching learning process is very crucial. To be effective in the teaching learning process, teachers must encourage different active teaching methods.

Teachers' education is also a part of professional development of teachers but, the teachers in our collage predominantly use conventional types of teaching methods that are very familiar to them, perhaps even the ones that they themselves experienced when they were students at schools.

So, this study attempted to survey the application of active learning methods in specific reference to Robe, Asela and Adola techears Education College of oromia.

\subsection{Statement of the Problem}

Some local studies were conducted in relation to the application of active learning in universities, colleges and some government schools of Ethiopia. Among them is "The Implementation of Active Learning, Case of Kotebe College of Teacher Education" by Tibebu Tekletsadik in 2006. His major finding indicates that the magnitude of practicing active learning is very low. The other study conducted by Oli Negassa in the same year was entitled "The status of Active Learning Approach in the Teacher Education Colleges of Oromia Region." His study revealed that the use of active learning practice in the teacher education colleges varied. Yet, another researcher, Yonas Amdemeskel conducted a case study on factors that affect the application of active learning in primary schools of west Harerghe. The study reported that large class size, shortage of instructional material, lack of skills in selecting a variety of methods and lack of awareness on what active learning is, are the major factors that affect the application of active learning. However, none of these studies were actually intended to examine application of active learning methods in Physical education class during in case of some selected colleges of teacher's education in Oromia Regional State. Therefore, none of the above studies tried to assess application of AL in PE class that must not be neglected in PE classrooms.

The traditional "chalk and talk" approach with the students as a recipient of knowledge may not suitable for today's generation. instructors of PE in our college have positive attitude towards the application of active learning but they practiced some times. The majority of them usually adhered to lecture method of teaching. Here what strikes the mind of the researcher is that no more attention is given to active learning application.

The above facts made the researchers to develop an interest in closely studying the situation of the application of active learning methods in Physical education classes by teachers of some selected Colleges of Teachers Education in Oromia. Because, the colleges are teacher producing and also a part of professional development of teachers and that the graduating teachers should be taught by teachers who practice active learning methods in their classes, so that there would be assurance that the graduate teachers would practice active learning in their future classes.

So that, the purpose of this study was to examine the challenges of application level of active learning in PE Robe, Asela and Adola college of techears education in oromia and to identify the factors that may be affecting the application of 
active learning.

Finally, to give feasible recommendations that encourages the application of active learning methods. Hence, the study was attempts to find out answers for the following investigative research questions:

- How is the application of active learning methods in the college of teacher education

- Do teachers' use a variety of teaching methods and techniques during physical education class?

- Do teachers' believe that the instruction materials are conducive for the application of active learning?

- What are the major challenges of the college teachers hindering their efforts of applying active learning methods in their physical education classes?

\subsection{Scope of the Study}

The researcher believes that, it could be better to conduct the study in large scale. However, due to time constraint, the researcher was delimited the area of the study only in 3 selected teacher's education college of Oromia. Those were Robe Teacher's Education College, Asela teachers education collagee and Adola teachers education collage. Even though, those College have 1-3 year students, the study is delimited to $3^{\text {rd }}$ year PE students and only 9 physical education teachers. Although it is impossible to cover all areas of the study due to lack of time and money the study is limited in assessing the challenges for application active learning methods and how active learning is applied in selected teacher's education college of Oromia.

\subsection{Significance of the Study}

It is obvious that, the quality of instruction which is realized through effective teaching and learning determines the quality of education. Assessing the challenges of active learning approach applying in PE the selected teacher's education college of Oromia is the main purpose of this study. Accordingly, the researcher believes that, this study will have the following significance.

- It will help the teachers to undertake self-assessment regarding usual teaching methods.

- It will show the level of practicality of activate learning application in those teacher's college of Oromia.

- The study may create awareness about the current status of the application of active learning in selected teacher's education college of Oromia.

- It contribute in indicating problems, lacks and gaps in the selected teacher's education college of Oromia.

- It may emphasized to give awareness on the challenges for applying active learning approach in teaching physical education in selected teacher's education college of Oromia and the perspectives of their stuffs.

- It may initiate other researchers to conduct similar study at a wider scale and serves as a stepping stone for further research in the field.

\subsection{Objectives of the Study}

\subsubsection{General Objective}

The general objective of this study is assessing the application of active learning methods in PE the selected college of 
teacher's Education of Oromia.

\subsubsection{Specific Objectives}

The Specific objectives of this study are:-

- To determine whether the teacher's education college have sufficient and suitable facilities and equipment to implement active Learning methods.

- To evaluate how physical education teachers selected from teacher's education college of Oromia is applying active learning.

- To identify the promoting and hindering factors of applying active learning in physical education class.

- To suggest the need for well-organized application of active learning in selected teacher's education college of Oromia.

- To identify what teaching approaches and techniques teacher use during PE class.

- To identify the teachers' awareness on AL and its contribution for students' learning.

\section{MATERIALS AND METHODS}

This chapter describes the description of the study Area, tools of data collection, and methods of data analysis and justifications for their selections, are described briefly.

\subsection{Discribtion of the Study Area}

These research was investigate in Robe, Asela, and Adola College of techear education on physical education teachers, college deans, and $3^{\text {rd }}$ year physical education students. Which is $430 \mathrm{~km}, 175 \mathrm{~km}$ and $471 \mathrm{~km}$ respectively distance from Capital city of the country (Addis Abeba) at East west direction of Bale Zone Oromia regional state.

\subsection{Source of Data}

For this study the researcher use primary and secondary data source. The primary data was gathers from the students, physical education teachers, college deans, and Class room and field observations to assess the challenges of applying active learning in the selected collages of teacher education in Oromia..

The secondary data was obtain from document analysis, books and different reference materials related with the active learning application.

\subsection{Research Design}

To conduct this research, the researcher used a descriptive survey method of research. To achieve this, descriptive survey design was used because it enables the researcher to generate ideas, opinions and beliefs of relatively large number of respondents and diverse groups (Creswell, 2003). And it save time and cost because of limited number of units from the population of the study are investigated. Also, it can lead to a greater accuracy because of close monitoring and supervision of the data collection, analysis and interpretation are much more feasible. The aim of survey design is to study the sampled population and be able to generalize the findings to the population from which the sample is drawn. 
Generally, the study was focused mainly on describing, identifying, analyzing and interpreting the current conditions that exist in relation to the application of active learning methods and factors that hinder application of active learning methods in Robe, Assela and Adola techears Education collage.

\subsection{Sampling and Sampling Technique}

The Oromiya region has a total of twelve techears educaton collages. For the purpose of study, the researcher selected only three collages of techears education as sample by using simple random sampling techniques. It is obvious that collages of techears education includes $1^{\text {st }}, 2^{\text {nd }}$ and $3^{\text {rd }}$ year students. Among those students, the researcher purposively took $3^{\text {rd }}$ year physical education students, because, the researcher believes that $3^{\text {rd }}$ year students are senior, familiar with the college environment and with their teachers' methodologies and also cover a broad areas, which provide the required data.

Concerning the selection of the respondents, the researcher selected $3^{\text {rd }}$ year physical education students', physical education teachers, and college deans. The researcher used availability sampling technique to select physical education teachers and college deans, since they are few in number. The total population of students in the three collages of techears education is 12 in number; among this the researcher took one third (1/3) or $33 \%$ of $3^{\text {rd }}$ year physical education students by using simple random sampling particularly the lottery method sampling technique and the sample is drawn proportionally from each techears education collges.

There are 8 physical education teachers, 3 college deans and students as a total population in the sampled collages of techears education. However, the sample size is made of all 8 physical education teachers 3 from Robe, 3 from Asela and 2 from Adola teachers college education and 3 college deans by using availability sampling technique, since they are few in number. The information from college administrators indicates that, there were 73 female 107 male and totally 180 $3^{\text {rd }}$ year physical education students in Robe collages of techears education, 45 female, 75 male and totally $1203^{\text {rd }}$ year physical education students in Assala and 31 female, 49 male and totally $803^{\text {rd }}$ year physical education students in Adola collages of techears education

From these, the total numbers of $3^{\text {rd }}$ year students the sample is 380. Among these the researcher took 33\% (126) of $3^{\text {rd }}$ year physical education students by using simple random sampling particularly the lottery sampling technique and the sample is drawn proportionally from each college.

\subsubsection{Data Collection Instruments}

In order to collect adequate and reliable data, the researcher used the Triangulation that means includes questionnaire, personal observation and interview as data gathering tools.

\subsubsection{Class room observation}

Observation is one way of data collecting instruments. In the application of an educational program, it is in the "class room" that all hidden and manifest intentions and efforts of education occur. Based on this, we can say that classroom is very important source of data collection in describing the application of an educational innovation. Therefore, classroom observation was taken as one of very important source of data in this study. The observation was takes place while the teachers were teaching both practical and theoretical part of the lessons. The class room observation guide format/check list was developed by the researcher. 
Based on observation check-list a critical observations of the classrooms (both theory and practice) realities such as teaching methods of teachers employ, the major activities the teachers and the students perform, participation, interaction between teachers and students, the classroom conditions and other necessary facilities were observed.

\subsubsection{Interview}

Interview is a very useful instrument to understand reasons why and how things happen and the way they happening. The major way in which any researcher seeks to understand the perceptions, feelings and knowledge of people in programs is through in-depth and intensive interviewing.

To gather more detailed information from teachers, and college deans the researcher employed semi structured interview. It is because these people were small in number and their position is important in describing whether an educational program is being implementing as planned or not. Thus, it is with this assumption that interview was employ as a data gathering instrument for this study. Before starting the interview, the interviewees was inform about the purpose of the study. During the interview, the response of all interviewees was record by using a tape recorder. The response of the interviewees was analyze and incorporate into the final report of the study.

\subsubsection{Questionnaire}

Questionnaires is avery important instrument in the process conducting research for the collection of data. The questionnaire was designed as both open ended and close ended items in English and translated into Afan Oromo to minimize misunderstandings and misinterpretations by respondents. In general the same items for both teachers and students were match (relate) with each other, this means, the same items reflect in one another. This was done in order to cross check the accuracy of data.

The researcher prepare questionnaire, pilot testing of the instrument was made on one randomly selected Bulee hora teacher education college from non-sampled college. Thus it provided a trial run for the questionnaire that involved testing the wording of the questions, identifying ambiguous questions, determining how long it takes to complete the questionnaire, and if all important content has been included. A pilot study enhances the content validity of the questionnaire. The pilot test was conducted on 15 respondents (Two college dean, three teachers, and ten students). In addition to this, to confirm the validity of the instrument, the questionnaires was distributed among 5 experts in the area of education from different position. Based on their valuable comments and suggestions necessary adjustments were made as far as the clarity of language, ideas and contents of study was concerned. Finally, questionnaires were distributed to the respondents.

\subsubsection{Procedure of Data Collection}

As long as the procedure of data collection is concerned, the researcher was got through the following steps, so as to collect the relevant data. The first thing have to do was getting permission from the dean of collages. After the researcher gots permission, he was distributes the questionnaires to the respondents, after precise introduction so as to let them to know the purpose of the study. Next, the researcher was observe classroom activities (both theory and practical classes). Then the researcher was interview the college's dean and physical education teachers by preceding smooth introduction to create clear/good relation and as to get very relevant data. Finally, after data collected from respondents, the researcher was like to address his acknowledge for all people those corporate him. 


\subsection{Methods and procedure of Data Analysis}

The data collected with the above mentioned instruments were presented in two forms. The first type of presentation was the discussion of the findings sometimes supported by theoretical arguments. The quantitative data collected using the questionnaires were tabulated and fed into the SPSS 16.0 for windows statistical software to change the raw data into the percentage in tables, frequency of response in the table was represent how many times a particular response appeared in different items.

The data collected through observations were present in percentage forms in the table and then the discussion of data thoroughly presented below the table in order to made clear and easily understandable to the reader, supporting by the theoretical arguments.

The other form is the data was collected through subjective questions (open ended) and interview were organized and presented in the form of paragraph, supported by theoretical argument.

\section{SUMMARY, CONCLUSIONS AND RECOMMENDATIONS}

\subsection{Summary}

The purpose of this study was to assess the application of active learning methods in pe the selected college of teacher's education of oromia and to come up with remedial solutions in order to improve the current practices active learning. To this end, descriptive survey design research design was adopted to carry out the study. In addition, the study was utilized mixed method approach through collecting and analyzing both qualitative and quantitative data. In order to solve the aforementioned problems the following basic questions were raised in the study:

- How is the application of active learning methods in the college?

- Do teachers' use a variety of teaching methods and techniques during physical education class?

- Do teachers' believe that the instruction materials are conducive for the applying of active learning?

- What are the major challenges of the college teachers hindering their efforts of applying active learning methods in their physical education classes?

The study was used both primary data sources and secondary data sources. Data that are essential for the study were collected by using questionnaire, personal observation and interview as data gathering tools. The subjects of the study are teachers, students and college deans. Out of the total number of 100\% (8) of teachers, 33\% (126) of students and 100\% (3) college deans were taken as a sample. The samples were selected from 3 college of teachers' education using simple random sampling techniques. Both students and teachers were selected to fill questionnaire through simple random sampling and availability sampling respectively. The college deans were also selected using purposive sampling technique to respond for interview. Out of the total number of questionnaires distributed to students and teachers, 123(97.61\%) and $8(100 \%)$ respectively were properly filled, returned and thus used in the analysis of data. Both quantitative and qualitative data gathered through tools of data obtained were analyzed by using mean scores, t-test, frequency and percentage. Depending on the analysis of the result made, the following major findings were obtained.

The educational background of the sampled respondents is ba/bsc degree holder. Of these 3 instructors that are ba degree holders in pe. The rest were master holder. So, it is good if measures are taken to cover the college with second 
degree holder. There was no any female teachers and college deans in sample colleges. Therefore, it is better if females will be encouraged to be teacher or college deans.

- How is the application of active learning methods in the ocllge

The perceptions of teachers and students on the current active learning application process of pe in different colleges oromia was tested. Some of these activities were found at low rate. Because, most activities were not performed all in all with more than 50\%. These were: lack of clarifying the learning objective, lack of encouraging students to become actively participate in the class room, lack of inviting students to reflect their idea on the daily lesson and on the learning process itself, lack of giving constructive feedback for students, lack of associating, relating and matching the classroom lesson with the real life experience of students and lack of creating activities (problem) that requires higher order thinking and critical thinking skills. In contrast, the following activities were perceived as they were performed at high rate. This was use the learning objective during classroom teaching.

- Do teachers' use a variety of teaching methods and techniques during physical education class?

Regarding the use a variety of teaching methods and techniques during physical education class in different college of teachers education in oromia regional state, the following teaching methods were apply at low rate. These were: discussion, group work, problem solving, peer teaching, think-pair-share, cross over, pyramiding and jigsaw group. The most utilized methods of teaching were lecture/command, cooperative and practice. Out of different methods named as active method of teaching cooperative and practice were better performed.

- Do teachers' believe that the instruction materials are conducive and have sufficient facilities for the applying of active learning?

Concerning the instruction materials are conducive and have sufficient facilities for the applying of active learning in oromia teachers college the study area, the most fulfilled facilities were: the ratios of students to instructional materials are balanced for pe practical classes, there are sufficient desks and chairs in my classrooms, the library facilities are motivating students for reading and there are adequate teachers for teaching pe subject. In contrary the following issues were poorly found in colleges. These were: lack of adequate text book available for teaching pe subject, lack of adequate different sport materials such as balls, javelin, shot put, hurdle etc, and there are insufficient reference books in the library related to pe subject.

- What are the major challenges of the college teachers hindering their efforts of applying active learning methods in their physical education classes?

In relation to the major challenges of the college teachers hindering their efforts of applying active learning methods in their physical education classes, the most dominants challenges were: asking many questions from the students, presence of large classes students, amount of content that needs to be covered, lack of administrative support in financially and facilitation, lack of classroom space inhibits group work, involve students in active learning will add too much to my work load lack of resorce and lack of understanding how to apply active learning.

\subsection{Conclusions}

Based on major findings of the study the following conclusions were drawn. 
- As the finding of this study revealed, the majority of the activities in the teaching learning process using active methods of teaching were not effectively applied by college physical education teachers. Particularly, as the finding of the study revealed, college teachers were poor in clarifying the learning objective, inviting students to reflect their idea on the daily lesson and on the learning process itself, giving constructive feedback for students and creating activities (problem) that requires higher order thinking and critical thinking skills. Therefore, from the finding, it is possible to conclude that teachers of Oromia Regional States Teachers' Education College were not effective to apply active learning during physical education in relation to learning teaching process.

- Regarding usage of variety of teaching methods and techniques during physical education class, the finding revealed that college teachers of physical education have not satisfactorily applied active learning techniques. The most dominant was lecture method. Some of these were less applied active learning methods: group work, problem solving, peer teaching and pyramiding. Therefore, it is possible to conclude that college teachers of physical education were not effective in realizing the application of active learning and their method of teaching was full of lecture.

- With regards to the instruction materials are conducive and have sufficient facilities for the applying of active learning were also found at poor level. Specifically, there are was sufficient reference books in the library related to PE subject, there are adequate text book available for teaching PE subject, and there are adequate different sport materials such as balls, javelin, shot put, hurdle etc. were supported by less number of participants. Consequently, the colleges of teachers' education were ineffective in full filling the needed instructional and facilities of active learning to make education effective.

- Finally, it is possible to conclude from the result that, large classes' students, large amount of content that needs to be covered, lack of classroom space inhibits group work, assuming involvement of students in active learning will add too much to my work load and lack of understanding how to apply active learning methods were the major challenges that affect the college teachers in applying active learning. It is obvious that all this challenges can negatively affect the application of active learning and in turn the teaching learning process as a whole. Therefore, college teachers and its administrative bodies should strive to minimize these challenges by monitoring the day to day activities. College deans are also responsible a help and capacitate teachers through in-staff training.

\subsection{Recommendations}

Based on the conclusions drawn, the following possible recommendations were made.

- As the finding revealed, college teachers did not sufficiently apply usage of different active learning methods of teaching and extra teaching materials. Therefore, it is advisable that college deans and department heads of need to encourage teachers to use different active learning methods and extra teaching materials in the classroom to promote improved learning achievement and make sure of its realization.

- The college deans and different administrative bodies did not engage themselves in effective managing day to day operation and needed financial and technical support. This affects negatively the teachers and classroom instruction. Hence, the Management team of the college should give due attention for the practical application of active learning function to influence the teaching learning process. 
- The study tells that physical education teachers are not active in inviting students to reflect their idea on the daily lesson and on the learning process itself and giving constructive feedback for students. Therefore, teachers should improve the relationship and contact with their students positively and give immediate feedback for students after presentation.

- The study reveals that as the lack of understanding how to apply active learning. So The OEB (Oromia Education Bureau) should give continuous chance for In-service training focused on instructional skills and demonstration for practices was key elements for PE teachers' mastery of instructional methods. Therefore, it seems important to provide relevant, practical and participatory pre-service and in-service training. Also it seems important if all teachers have access to training through workshops, videos, model projects and up to date literature.

- As the result of the finding revealed, Teachers' education colleges of Oromia had shortage of sufficient reference books in the library related to PE subject and different sport materials such as balls, javelin, shot put and hurdle. Therefore, College leaders in collaboration with OEB need to identify problems in the colleges and should allocate sufficient budgets for the department so that the department of physical education can fulfill important facilities and reference books.

- Physical education is an active education which needs the active involvement of students and it needs strong interactions between the teachers, the students and the curriculum by its nature. But it can be passive where the absence of this interaction and with institutional and societal problems that challenge the effective ongoing process of learning and also the existence of the department. Instructional materials facilitate active learning, encourage and creative thinking, relate theory with practice and make learning more functional by increasing retention. However, the study revealed those teachers were not using the necessary instructional materials (teaching aids) as it needed. Therefore, it seems important to strengthen more college pedagogical centers (made special for physical education department), provide budget and initiate teachers and students to play their part in AL application.

- In-service training focused on instructional skills and demonstration for practices was key elements for PE teachers' mastery of instructional methods. Therefore, it seems important to provide relevant, practical and participatory pre-service and in-service training. Also it seems important if all teachers have access to training through workshops, videos, model projects and up to date literature.

\section{ACKNOWLEDGEMENTS}

In the course of writing this research, I have been provided the help and assistance by many individuals and institutions. Among these,

I would like to express my deepest gratitude to Robe college of teacher education for their financial and materials support in the undertakings of this study. I would like to express also my deepest gratitude to my frend Mukter Abdulkarim for his knowledge support and encouragement to undertaking of this study. My heartfelt gratitude and appreciation goes to my wife, Furno Ayele. It was through her strong initiation, encouragement and support that my under graduate, postgraduate and this study has become a reality. I use this opportunity to appreciate and thanks Abdulhakim abduselam, Mukter badewi, Abdurahman Worku, Kebede Areda, Ustaz Kamil Aliyi, Kadir Muhe, for their moral support to make this study to its destination. 
I also indebted to all the PE teachers and students of College of teacher education of oromiya for their genuine cooperation and willingness to contribute to the study by being the source of necessary data and information in the undertakings of this study. I am greatly thankful to the College deans of above stated college. I also thank the enumerators for their participation in the collection of much of the field data and information.

Finally, I thank all those who in one way or another have contributed to the success of my study.

\section{REFERENCES}

1. Achike, F.I. \& Nain, N. 2005. Promoting problem-based learning in nursing education: A Malaysian experience. Nurse Education in Practice, 5: 302-311.

2. Adams, S., and Burns, M.1999. Connecting Student Learning antechnology. Retrieved,January20/1/2013 http://www.southcentralrtec.org/products/cslt.

3. Aggrawal, J.C. 1996. Principles, Methods and Techniques of teaching. Vial publishing house put New Delhi.

4. Ainsworth, S. 2006. DeFT: A conceptual framework for considering learning with multiple representations. Learning and Instruction, 16: 183-198.

5. Bedru Kedir.1998. "Learner-centered Education and Its Methodology."(Training Module). Addis Ababa, Education Sector Development Programme.

6. Benedict, J.O. \& Anderson, J.B. 2004. Applying the just-in-time teaching approach to teaching statistics. Teaching of Psychology, 31:197-199.

7. Bernard, A., David, D., Sylvester, $O$ and Olatunji, J. 2013. Attitude of primary school mathematics teachers towards the use of activity- based learning methods in teaching Mathematics in Nigerian schools. International Journal of Education Learning and Development. Vol.1, no.1, pp.22-36. Retrieved on august 10, 2015, from www.eajournals.org/.../attitude-of-primaryschool-mathem.

8. Bernet et.al. 1995. Researching into teaching methods in colleges and universities. London kogan page.

9. Birhanu, M.A. 2010. Active learning approaches in mathematics education at Universities: in Oromia, Ethiopia. Unpublished PhD Dissertation. Submitted in accordance with requirements for the doctor of education. University of South Africa. Retrieved May, 8,from http://uir.unisa.ac.za/bitstream/handle/10500/4133/thesis_alemu_b.pdf?sequence=1

10. Bonwell, C., and Elison, A., 2003. Active Learning Creating Excitement in the Classroom

11. Bonwell, C.C., and Eison, J.A. 1991. Active learning Creating Excitement in the Classroom. Washington, Gorge Washington University Press. Rhen:Grips

12. Borich, G. 1988. Effective Teaching Methods. New York, Macmillan Publishing.

13. Bransford, J.D. 1984. Human cognition, learning understanding and remembering. Belmont.

14. Brookfield, Stephen P. and Preskill, Steven. 1999. Discussion as a way of teaching, Tools and techniques for democratic classrooms. San Francisco : Jossey-Bass, pp. 22-23.

15. Brown, H.D., 1994. Principles of Foreign Language Teaching. Cambridge, Cambridge University Press.

16. Bryndin, Evgeniy. "Development of sensitivity and active behavior of cognitive robot by means artificial intelligence." International Journal of Robotics Research and Development 10.1 (2020): 1-11. 
17. Callhan Joseph. 1988. Teaching in middle and secondary schools: planning for competence. New York Macmillan publishing company.

18. Capel et.al. 1995. Learning To Teacher in the Secondary Schools. London Rutledge.

19. Cecily, Helen Shaji John, and Akram Omoush. "Efficacy of Problem Based Learning (Pbl) Over Lecture Method in Enhancing The Critical Thinking Skills and Problem Solving Ability Among Nursing Students In KSA." International Journal of Educational Science and Research (IJESR) 4.5 (2014): 1-8.

20. Chet et.al. 1993. Promoting active learning strategies for high school classrooms. San Francisco josses, Base.

21. Chriskyriacou, C. 1998. Essential Teaching Skills, 2nd Edition. London, Nelson Thrones.

22. Cohen, D. K., Raudenbush, S. W., \& Ball, D. L. 2002. Resources, Instruction, and Research. In I. F. Mosteller \& R. Boruch (Eds.), Evidence matters: Randomized trials in education research (pp. 80-119). Washington, DC: Brookings Institution Press.

23. Commonwealth of Australia. 1992. Physical and sport education: a report by the Senate Standing

24. Darst, P.W., \& Pangrazi, R. 2006. Dynamic physical education for secondary school students (5 ${ }^{\text {th }}$. Ed.). San Francisco, CA: Benjamin Cummings.

25. Dary, N. and Terry, E. 1993. Reforming Open and Distance Education: Critical Reflection Practice. London, Kogan page.

26. Derri, V. \& Pachta, M. 2007. Motor skills and concepts acquisition and retention: a comparison between two styles of teaching. Revista Internacional de Ciencias del Deporte. 9(3), 37-47.

27. Dewing, J. 2008. Becoming and being active learners and creating active learning workplaces: the value of active learning. In: McCormack, B., Manley, K., Wilson, V. (Eds.), International Practice Development in Nursing and Healthcare. Blackwell, Oxford, pp. 273-294.

28. Eggen, P.D and D.P, Kauchax. 1996. Strategies for Teachers: Teaching Content and Thinking Skills. Boston, Allyy and Bacon.

29. Egwunyenga, E. J., \& Enueme, C.P. 2008. Principals' instructional leadership roles and effect on teachers' job performance: A case study of secondary schools in Asaba Metropolis, Delta State, Nigeria. J. Soc. Sci., 16(1): 13-17. Retrieved on June 29, from www.krepublishers.com/...JSS-16-1-013-08-513-Enueme-C-P-Tt.pdf

30. Elizabeth, Leu. 1999. Participation and ability of the learners. In Journal of Education.

31. Ellis, A. L., Wagner, E. D. and Longmire, W. R. 1999. Managing Web-based training: How to keep your program on track and make it successful. Arlington, VA: ASTD Press.

32. ETP, 1994. Education and Training Policy. Ministry of Education, Addis Ababa, Etiopia..

33. Farant, J.S. (2000). Principles and Practice of Education (New Edition). Singapore: Longman.

34. Farooq, M., \& Shahzadi, N. 2006. Effect of Teachers' Professional Education on Students' Achievement in Mathematics. Bulletin of Education \& Research June 2006, Vol. 28, No. 1, pp.47-55

35. Fiseha Abrana. 2001. Active Learning: MA Thesis (Unpublished) Materials, AAU

36. Gallahue, D. (1996). Developmental Physical Education for Today's Children. Dubuque.

37. Gallahue, D.L. 1987. Developmental physical education for today's elementary school children. Champaign, IL: Human Kinetics

38. Garn, A., \& Byra, M. 2002. Cognitive, psychomotor, and cognitive development spectrum style. Teaching Elementary Physical Education, 13(2), 8-13. 
39. Good, T.L and Brophy, J.E. 1994. Looking in Classroom, Varper Collins College publisher. New York. NY.

40. Graham, G.; Holt/Hale, A.S. \& Parker, M. 2003. Children Moving: A reflective approach to teaching physical education (6th Edition). USA: McGraw- Hill.

41. Griffin, L., Mitchell, S. \& Oslin, J. 1997. Teaching Sports Concepts and Skills: A tactical games approach, Illinois: Human Kinetics.

42. Hailom Banteyerga. (2008). Explorations towards an Alternative Model in Teacher Education Classroom in focus in quality Education in Ethiopia, Visions of 21 st Century. Addis Ababa: IER.

43. Hastie, P.A., \& Saunder, J.E. 1991. Effects of class size and equipment availability on student involvement in physical education. The Journal of Experimental Education.

44. Healey, M., \& Roberts, J. 2004. Engaging students in active learning: case studies in geography, environment and related disciplines. Cheltenham: University of Gloucestershire Yayıncılı.

45. Heneveld, W. \& Craig, H. 1996. World Bank, Project Designs \& the Quality of Primary Education in Sub-Saharan Africa. Washington: World Bank.

46. Hmelo-Silver, C.E. 2004. Problem-based learning: What and how do students learn? Educational Psychology Review, $16(3): 235-266$.

47. ICDR, 1999. The Education Hand Book. Addis Ababa: Finfinne Printing and Publishing Press.

48. Knapp, Clyde., and Hagman, E. 1953. Patricia. Teaching Methods for Physical Education. New York: McGraw-Hill Book Company.

49. Kyrincou, C. 1998. Essentials of teaching skills, (2nd . Ed.). London: Nelson Thrones.

50. Leu, E. 2000. The Role of Curriculum Integration in Basic Education. Tigrai Education Bureau. Addis Ababa University, Addis Ababa, Ethiopia.

51. Lockheed et.al. 1991. Improving Primary Education in Developing Countries. Washington: Oxford University Press.

52. Lockheed et.al. 1991. Improving Primary Education in Developing Countries. Washington: Oxford University Press.

53. Lue, 1998. Designing integrated Curriculum materials for Primary Education. A paper Presented at the Workshop in Oromia.

54. Macharia, S.N and Waria L.M. 1994.Teaching practice in Primary Schools. Kongkong: macmillan Publishing Company.

55. McKenzie, T. L., Alcaraz, J. E., Sallis, J. F., \& Faucette, F. N. 1998. Effects of a physical education program on children's manipulative skills. Journal of Teaching in Physical Education, 17(3), 327-341.

56. Michael, J. 2003. Where's the evidence that active learning works? a Working Model of Helping the Learning to Learn. Mahwah, NJ: Erlbaum.

57. Michael, P. 2004. Does Active Learning Work? Review of the Research, Bucknell University,Lewisburg.

58. Ministry of Education. 2002. The education and training policy and its implementation. Addis Ababa: Ministry of Education.

59. MOE (Ministry of Education). 1994. The Education and Training policy of the Federal Republic of Ethiopia, Addis Ababa, Ministry of Education (EMPDA).

60. MOE (Ministry of Education). 2003. TESO Pre-service Committee a national Curriculum Guideline for Pre-service Teacher Education programs. AAU (Unpublished) 
61. Monere. Walters Editors. 1956. Encyclopedia of education research, New York: Macmillan company.

62. Mosston, M. and Ashworth, S. 2002. Teaching Physical Education, 5th edn. San Francisco: Benjamin Cummins.

63. Mosston, M., \& Ashworth, S. 1994. Teaching physical education $\left(4^{\text {th }}\right.$ ed.). New York: Macmillan.

64. Moses, Chinonye, et al. "Entrepreneurship education and action-oriented pedagogical approaches." International Journal of Educational Science and Research 5.5 (2015): 53-60.

65. Mukalel. J. 1998. Creative Approaches to Classroom Teaching. New Delhi: Discovery.

66. Nardos Abebe. 2000. Issues and Methods and Materials in Teaching Primary School Subject Addis Ababa. AAU.

67. Nichols, B. 1994. Moving and learning: The elementary school physical education experience ( ${ }^{\text {rd }}$ Ed.). Dubuque: William C. Brown

68. Nunan, D. 1988. The Learner-centered Curriculum. Cambridge: Cambridge University Press.

Ode, E.O. 2014. Impact of audio-visual (avs) resources on teaching and learning in some selected private secondary schools in Makurdi, Nigeria. International Journal of Research in Humanities, Arts and Literature (IMPACT: IJRHAL). Vol. 2 , Issue 5. Retrieved on August 12, 2015, from www.impactjournals.us/download.php?... Impact\%20of\%20Audio...\%20.

69. Orlich, D et al 2001. Teaching Strategies: A Guide to Better Instruction (16th ed). Boston: Hough ton Mefflin Company.

70. Petty, G. 2004. A practical Guide: Teaching Today 3rd Edition. United Kingdom: Nelson Thormes Ltd. Planning Your Course: A Decision Guide. Center for Learning and Teaching, Cornell University. http://www.cte.cornell.edu/faculty/materials/CoursePlanningQuestions.pdf.

71. Plass, H. 1998. "The Learner-Centered Classroom” in Quality Education in Ethiopia: Visions For 21st Century. Addis Ababa: IER.

72. Postareff, L., Lindblom-Ylanne, S., \& Nevgi, A. 2006. The effect of pedagogical training on teaching in higher education. Teaching and Teacher Education 23 (2007) 557-571. Retrieved on July 15, 2015, from www.helsinki.fi/.../artikk_lpostareff_the_effect_of_pedagogical_training

73. Saglam, H.I. 2011. An investigation on teaching materials used in social studies lesson. The Turkish Online Journal of Educational Technology - January 2011, volume 10 Issue 1. Retrieved on July 29, 2015, from www.tojet.net/articles/v10i1/1014.pdf.

74. Sguazzin, T and Graan M.V. 1998. Education Reform and Innovation in Namibia: How best can changes in class room practice be implemented and supposed: Proceeding from the 1998 NIED Educational Conference, Oka Handja 13-16 October, Namibia

75. Siedentop, D. 1994. Sport education: quality PE through positive sport experiences. Champaign, IL: Human Kinetics.

76. Siedentop. 2001. Introduction to Physical Education, Fitness and sport (4th .ed.). USA: Mayfield.

77. Silberman, M. 1996. Active learning: 101 strategies to teach and subject Boston: Allyn and Bacon.

Singh V.K and Singh Y.K. 2008. Physical Education Teaching Methods. New Delhi: Shree publishers and distributors.

78. Singh, J. 2005. Teaching of Science. Delhi: Ajay Verma.

79. Sirak Demelash. 2000. "Learner-centered Instruction in Teacher Training Institutes of Amharia Region", (M.A. Thesis). Addis Ababa University, Addis Ababa, Ethiopia. 
80. Slavin, R., Hurley, E.A. \& Chamberlain, A. 2003. Cooperative learning and achievement: theory and research, in: W. M. Reynolds \& G. M. Miller (Eds) Handbook of $\quad$ psychology: educational psychology. New York, Wiley, 7:177-198.

81. Smith, Edward. 1961. The Educators' encyclopedia, Engle Wood: Prince Hellenic.

82. Samaranayake, Sarath W. "The best method in EFL/ESL teaching." International Journal of English and Literature, 5 (5) 7380 (2015).

83. Smith. E. 1996. The Educators Encyclopedia. Englwood: Prince Hall. Inc.

84. Squazzin, T. and Grann, M.V. 1998. Education Reform and Innovations in Namibia. Okahandja: Namibia.

85. Taye Geresu. 2008. "Perception and Practices of Active learning in EFL Classroom” Addis Ababa University: M.A. Thesis (on line)

86. Temechegn Engida. 2001. Issues, Methods and Materials in Teaching Primary School Subjects.

87. TESO. 2003. Teacher Education System Overhaul Program Addis Ababa

88. Tirualem Ayelew. 2003. The Classroom Practice of Learner-Centered Approach in Secondary Cycle Primary Schools. MA Thesis. Unpublished, Addis Ababa University, Addis Ababa, Ethiopia.

89. Tozedv M., Steven, E., Paul, C. Violsen Guyb B. and Sense. 1993. School and Society: Educational Practice as Social Expression. New York: mcgraw Hill Inc.

90. Ulrich, D. 1985. Test of Gross Motor Development. Austin, T.X: Pro-Ed.

91. Vrasidas, C. 2000. Constructivism versus objectivism: Implications for interaction, course design and evaluation in distance education. International Journal of Educational Telecommunications, 6(4): 339-362.

92. Wallace, S. 2007. Teaching, Tutoring \& Training: in Lifelong learning sector 3rd Edition. Glasgow: Bell and Bain Ltd.

93. Weimer, M. 2002. Learner-centered teaching: Five keys changes to practice. USA: Jossey-Boss.

94. Weimer. 2002. “Five Learner Centered Practice Areas”. In Journal of Education.

95. Wright, T. 1987. Role of Teachers" and Learners". Oxford: Oxford University press.

96. Yara P Olatunde 2009. Student's attitude towards mathematics and academic achievement in some selected secondary schools in south-western Nigeria. Eur.J. Sci.Res.,36(3): 336-34 